\title{
Research Article \\ EFFECT OF FRONT LINE DEMONSTRATION ON SESAME IN EASTERN REGION OF RAJASTHAN
}

\section{KOTHYARI HUKAM SINGH ${ }^{1 *}$, MEENA K.C. ${ }^{2}$, MEENA B.L. ${ }^{3}$ AND MEENA RAMKISHAN4}

1,23Krishi Vigyan Kendra, Sawai Madhopur, 322001, Agriculture University, Kota, 324001, Rajasthan

${ }^{4}$ A.R.S., Agriculture University, Kota, 324001, Rajasthan

*Corresponding Author: Email-jadonhukam555@gmail.com

Received: February 28, 2018; Revised: March 06, 2018; Accepted: March 07, 2018; Published: March 30, 2018

\begin{abstract}
The Research study was conducted by Krishi Vigyan Kendra Sawai Madhopur during kharif-2017 under National Mission on Oilseed and Oilpalm (NMOOP) Project to enhancement the productivity and profitability of sesame by transfer of improved technology. The result revealed that the maximum seed yield of sesame was obtained under demonstrated plots ranged between $6.27 \mathrm{q} / \mathrm{ha}$ to $6.72 \mathrm{~g} / \mathrm{ha}$ with an average of $6.45 \mathrm{~g} / \mathrm{ha}$ which was 25.97 percent higher as compared to local check with an average of $5.12 \mathrm{~g} / \mathrm{ha}$. Extension gap between demonstrated plots and local check was found with an average of $1.33 \mathrm{~g} / \mathrm{ha}$. The maximum average net returns (Rs. 31190 ha $^{-1}$ ) and benefit cost ratio (2.70) were recorded under demonstrated plots as compared to local check (Rs. 22603 ha $^{-1}$ and 1.87 respectively).
\end{abstract}

Keywords- Sesame, Front Line Demonstration, Net return, B: C Ratio.

Citation: Kothyari Hukam Singh, et al., (2018) Effect of Front Line Demonstration on Sesame in Eastern region of Rajasthan. International Journal of Microbiology Research, ISSN: 0975-5276 \& E-ISSN: 0975-9174, Volume 10, Issue 3, pp.-1024-1026. DOl: http://dx.doi.org/10.9735/0975-5276.10.3.1024-1026

Copyright: Copyright@2018 Kothyari Hukam Singh, et al., This is an open-access article distributed under the terms of the Creative Commons Attribution License, which permits unrestricted use, distribution and reproduction in any medium, provided the original author and source are credited.

\section{Introduction}

Sesame (Sesamum indicum $L$ ) is called as 'queen of oilseeds crops' by virtue of its excellent oil quality. It is mainly cultivated in Rajasthan, Uttar Pradesh, Madhya Pradesh, Gujarat, West Bengal, Andhra Pradesh, Karnataka, Maharashtra, Tamil Nadu and Orissa. It is having the highest oil content (46-64\%) and dietary energy $(6355 \mathrm{kcal} / \mathrm{kg})$. its oil unlike other fats is highly stable and does not develop rancidity leading to loss of flavor and vitamin. India is the largest producer and exporter of sesame in the world Puspha, et.al.[1] Sesame is grown in an area of 7.54 million hectares with a production of 3.34 million tones in the world with a productivity of $443 \mathrm{~kg} / \mathrm{ha}$. China, Myanmar and Sudan account for $40 \%$ of the world's sesame production. In India, sesame is grown in about 1.8 million hectares with a total production of 0.76 million tones and productivity of $422 \mathrm{~kg} / \mathrm{ha}$. West Bengal alone accounts for $25 \%$ of the total sesame production in India. The other major sesame-producing states are Gujarat, Madhya Pradesh, Tamil Nadu, Maharashtra, Karnataka, Rajasthan and Uttar Pradesh FAl, [2]. Use of improved production technologies of sesame offers a great scope for increasing productivity and profitability. Keeping in this view front line demonstration on sesame was conducted to know improve the productivity and profitability of sesame in eastern region of Rajasthan.

\section{Materials and Methods}

The front line demonstrations were conducted on 125 farmer's field of five adopted village viz. Sinoli, Kustla, Jeevad, Padra, Mainpura of Sawai Madhopur District of Rajasthan during Kharif-2017 in Rain fed condition on low to medium soil fertility status. The package of practice of improved production technologies such as improved variety, seed treatment, plant protection measures were mentioned in demonstrated plots. Seed treatment is completed with carbendazim @ $2 \mathrm{~g} / \mathrm{kg}$ seed. Line sowing method is used for seed sowing in demonstrated plots. Row to Row distance $45 \mathrm{~cm}$ and Plant to Plant distance $10 \mathrm{~cm}$ is kept under Demonstration practices. $2.5 \mathrm{~kg} / \mathrm{ha}$ of Seed rate was kept under demonstrated plots. Recommended dose of fertilizer was applied through DAP, single super phosphate and Urea under demonstrated plots. Full dose of phosphorus and half dose of Nitrogen were given as Basal dose. The remaining half dose of Nitrogen was given by top dressing in two split doses at 30 DAS and 45 DAS. Weed management in demonstrated plots were done by hand weeding at 25 DAS. The crop was completed during 25 September to 15 October when the capsules are greenish yellow and leaves turns yellow colored. The technology index shows the feasibility of the evolved technology at the farmers' field. The lower the value of technology index more is the feasibility of the technology. The technology index is 19.37 percent for Sesame which shows the good performance by these varieties in eastern region of Rajasthan and this will accelerate the adoption of new varieties to increase the productivity of sesame in this area. The data were analyzed with appropriate statistical procedures. To estimate the technology gap, extension gap and the technology index the formulae given at the bottom of the page has been used. Samui, et., al. [3].

Technology gap $=$ Potential yield - Demonstration yield Extension gap $=$ Demonstration yield - Farmers yield Technology index $=\{($ Potential yield - Demonstration yield $) /$ Potential yield $\}$ $\mathrm{X} 100$

\section{Result and Discussion \\ Yield characters}

The data on yield attributing characters of sesame are presented in [Table-1] showed that the maximum seed yield of sesame was found under demonstrated plots ranged between $6.27 \mathrm{q} / \mathrm{ha}$ to $6.72 \mathrm{q} / \mathrm{ha}$ with an average of $6.45 \mathrm{q} / \mathrm{ha}$ as compared to local check with an average of $5.12 \mathrm{~g} / \mathrm{ha}$. Similar enhancement in seed yield of Sesame under demonstrated plots was reported by R. L. Saga, ret al [4], Deshmukh, et al. [5] and Patel, et al. [6]. Yield of the front line demonstration trials and potential yield of the crop was compared to estimate the yield gaps 
which were further categorized into technology gap and extension gaps Hire math and Nagaraju, [7]. The technology index indicated the feasibility of evolved at the farmer field. Lower the value of technology index more is the feasibility of the technology demonstrated $[4,8]$.

\section{Extension gap and Technology gap}

The data on Extension gap \& Technology gap of sesame are presented in [Table1] revealed that the extension gap between demonstrated plots and farmer's plots was recorded with an average of $1.33 \mathrm{~g} / \mathrm{ha}$. Technology gap of variety was found with an average of $1.55 \mathrm{q} / \mathrm{ha}$ due to lack of rainfall during flowering and pod formation stage. The results clearly showed that due to knowledge and adoption of scientific practices by the farmers, the yield of Sesame could be increased by 25.97 percent over the yield obtained under farmers' practices. The above findings were similar with the findings of Dubey, et al. [9] and Yadav, et al.[10]

\section{Economic Return}

The data on Economic return of sesame are presented in [Table-2] showed that the maximum gross return of crop was obtained under demonstrated plots ranged from $41620 \mathrm{Rs} / \mathrm{ha}$ to $44320 \mathrm{Rs} / \mathrm{ha}$ with an average of $42700 \mathrm{Rs} / \mathrm{ha}$ as compared to local check with an average of 34720 Rs/ha. Maximum Net return was obtained under demonstrated plots ranged from $30110 \mathrm{Rs} / \mathrm{ha}$ to $32810 \mathrm{Rs} / \mathrm{ha}$ with an average of $31190 \mathrm{Rs} / \mathrm{ha}$ as compared to local plots with an average of 22603 Rs/ha. Maximum B:C Ratio was obtained under demonstrated plots ranged from 2.61 to 2.85 with an average of 2.70 as compared to local check with an average of (1.87). Total cost of cultivation under demonstrated plots was found 11510 Rs/ha as compared to local check with an average of $12117 \mathrm{Rs} / \mathrm{ha}$. The result confirmed the similar findings of front line demonstrations on oilseed crops by Yadav, et al.[10], Singh, et al.[11] and Lathwal[12].

Table-1 Productivity, extension gap, technology gap and technology index of Sesame as grown under FLDS and existing package of practices

\begin{tabular}{|c|c|c|c|c|c|c|c|c|}
\hline Village & \multirow{2}{*}{$\begin{array}{c}\text { Area } \\
\text { (ha) }\end{array}$} & \multirow{2}{*}{$\begin{array}{l}\text { No. of } \\
\text { FLD's }\end{array}$} & \multicolumn{2}{|c|}{ Grain Yield(q/ha) } & $\begin{array}{l}\text { Increase } \\
\text { \% over } \\
\text { Control }\end{array}$ & $\begin{array}{l}\text { Extension } \\
\text { gap (q/ha) }\end{array}$ & $\begin{array}{c}\text { Technology } \\
\text { gap (q/ha) }\end{array}$ & $\begin{array}{c}\text { Technology } \\
\text { Index \% }\end{array}$ \\
\hline Sinoli & 10 & 25 & 6.72 & 5.29 & 27.03 & 1.43 & 1.28 & 16.00 \\
\hline Kustla & 10 & 25 & 6.56 & 5.20 & 26.15 & 1.36 & 1.44 & 18.00 \\
\hline Jeevad & 10 & 25 & 6.27 & 5.01 & 25.15 & 1.26 & 1.73 & 21.62 \\
\hline Padra & 10 & 25 & 6.40 & 4.99 & 28.26 & 1.41 & 1.60 & 20.00 \\
\hline Mainpura & 10 & 25 & 6.30 & 5.11 & 23.29 & 1.19 & 1.70 & 21.25 \\
\hline Mean & 10 & 25 & 6.45 & 5.12 & 25.97 & 1.33 & 1.55 & 19.37 \\
\hline \hline
\end{tabular}

Table-2 Gross Return, Net Return, Gross cost Cultivation \& BC Ratio of Sesame as grown under FLDS and existing package of practices

\begin{tabular}{|c|c|c|c|c|c|c|c|c|}
\hline \multirow{2}{*}{ Village } & \multicolumn{2}{c|}{$\begin{array}{c}\text { Gross Cost of Cultivation } \\
\text { (Rs/ha) }\end{array}$} & \multicolumn{2}{c|}{ Gross Return (Rs/ha) } & \multicolumn{2}{c|}{ Net Return (Rs/ha) } & \multicolumn{2}{c|}{ BC Ratio } \\
\cline { 2 - 9 } & Demos. & Local & Demos. & Local & Demos. & Local & Demos. & Local \\
\hline Sinoli & 11510 & 11850 & 44320 & 35740 & 32810 & 23890 & 2.85 & 2.01 \\
\hline Kustla & 11510 & 12120 & 43360 & 35200 & 31850 & 23080 & 2.76 & 1.90 \\
\hline Jeevad & 11510 & 11960 & 41620 & 34060 & 30110 & 22100 & 2.61 & 1.85 \\
\hline Padra & 11510 & 12225 & 42400 & 33940 & 30890 & 21715 & 2.68 & 1.78 \\
\hline Mainpura & 11510 & 12430 & 41800 & 34660 & 30290 & 22230 & 2.63 & 1.79 \\
\hline Mean & 11510 & 12117 & 42700 & 34720 & 31190 & 22603 & 2.70 & 1.87 \\
\hline
\end{tabular}

\section{Conclusion}

The research study clearly showed that the front line demonstration was effective in changing attitude of farmers against cultivation of sesame production technology. The above results showed that the maximum seed yield of sesame under demonstrated plots higher ( $6.45 \mathrm{~g} / \mathrm{ha})$ as compared to local check (5.12 $\mathrm{q} / \mathrm{ha}$ ). The maximum net return (Rs. $31190 \mathrm{ha}^{-1}$ ) and Benefit Cost Ratio (2.70) were recorded under demonstrated plots higher as compared to local check (Rs. 22603 ha-1$^{-1}$ and 1.87 respectively). Thus, Front Line Demonstration was helpful in replacement of local varieties with improved varieties of Sesame crops.

Application of research: this study could be useful for extension researcher and farmers.

Research Category: Agriculture Technology Application.

Abbreviations: Rs- Rupees, ha-1- per hectare,

Acknowledgement / Funding: Authors are thankful to Krishi Vigyan Kendra Sawai Madopur, Rajasthan and CFLD's farmers.

${ }^{*}$ Research Guide or Chairperson of research: Dr K. C. Meena

University: Agriculture University, Kota, 324001, Rajasthan

Research project name or number: National Mission on Oilseed and Oilpalm
Author Contributions: All author equally contributed

Author statement: All authors read, reviewed, agree and approved the final manuscript

\section{Conflict of Interest: None declared}

Ethical approval: This article does not contain any studies with human participants or animals performed by any of the authors.

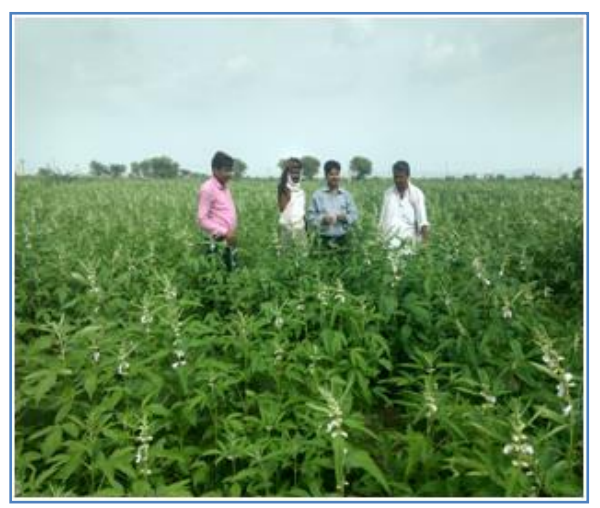

Fig -1 FLD's on Sesame Variety RT-351 at Sinoli Village 


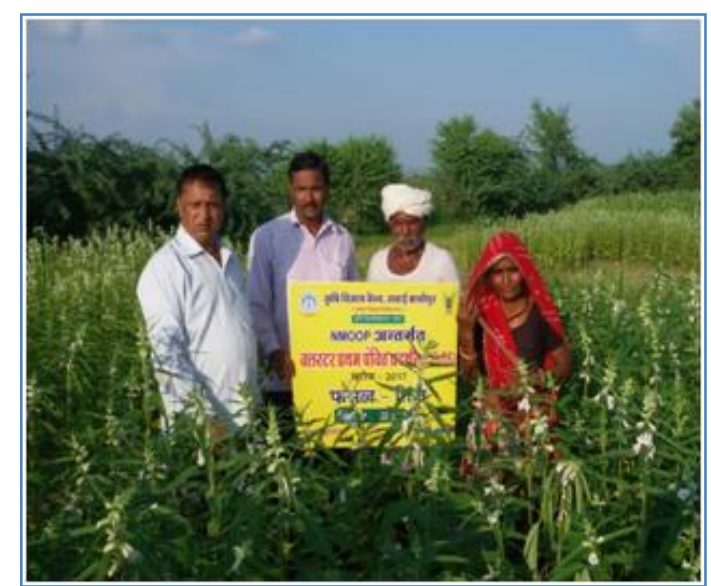

Fig -2 Histogram: Cluster front line demonstration in Kustla village of Sawai Madhopur

\section{References}

[1] Puspha R. and Senthil Kumar P. (2003) Studies on the combing ability in sesame (S. indicum L.) paper presented in the National Seminar on 'Advances in genetics and Plant breeding', Impact of DNA Revolution, October 30-31, 2003, University of Agricultural Sciences, Dharwad, Karnataka, India.

[2] FAl (2011) Fertilizer Statistics, Fertilizer Association of India, New Delhi.

[3] Snmui S.K., Maitra S., Roy O.K., Mondal A.K., Saha D. (2000) Journal of the Indian Society of Coastal Agriculture Research, 18(2), 180-183.

[4] Sagar R.L. and Chandra G. (2004) Agriculture Extension Review,16(2), 710.

[5] Deshmukh G., Patel H.B. and Patel M.R. (2014) Gujarat Journal of Extension Education, 25(1), 27-30.

[6] Patel R.N. and Patel J.R. (2014) Gujarat Journal of Extension Education, 25(1), 91-92.

[7] Hire math S.M. and Nagaraju M.V. (2009) Karnataka Journal of Agricultural Sciences, 22 (5), 1092-1093.

[8] Kumar S., Singh R. and Singh A. (2014) Indian Research Journal of Extension Education, 14 (2), 20-24

[9] Dubey S., Tripathi S., Singh P. and Sharma R.K. (2010) Journal of Progressive Agriculture, 1(1), 42-44.

[10] Yadav D.B., Kamboj B.K. and Garg R.B. (2004) Haryana journal of Agronomy, 20 (1\&2), 33-35.

[11] Singh Jagmohan, Dhillon B.S., Asthaand Parvinder Singh (2012) Asian Journal of Soil Science, 7(2), 315-318.

[12] Lathwal O.P. (2010) Annual Agriculture Research, 31(1\&2), 24-27. 